\title{
Catheter drainage of spontaneous pneumothorax: suction or no suction, early or late removal?
}

\author{
SY SO, DYC YU \\ From the Department of Medicine, University of Hong Kong, Hong Kong
}

ABSTRACT Twenty-three patients with primary spontaneous pneumothorax and 30 patients with secondary spontaneous pneumothorax treated by intercostal catheter drainage with underwater seal were divided randomly into two groups, one receiving suction drainage (up to $20 \mathrm{~cm} \mathrm{H}_{2} \mathrm{O}$ pressure) and the other no suction. The success rate was $57 \%$ for the former and $50 \%$ for the latter. The suction group spent an average of five days in hospital, whereas the non-suction group averaged four days. Suction drainage therefore did not have any advantage. To determine how soon the catheter could be removed without complication, patients were also divided randomly into two subgroupsone had the catheter removed, without previous clamping, as soon as the lung was expanded; the other had the catheters left in situ for a further three days. The success rate was $52 \%$ for the former, and $53 \%$ for the latter. But most of the failure in the early removal group was caused by re-collapse of the lung rather than persistent air leakage; hence removal of the catheter too early was not recommended.

Spontaneous pneumothorax is usually treated by insertion of an intercostal catheter connected to underwater seal drainage. However there is no agreement on the routine use of suction drainage. Several textbooks on respiratory medicine in fact gave conflicting views. Croften and Douglas ${ }^{1}$ were against suction; Holman ${ }^{2}$ seemed to recommend it whereas Hinshaw and Murray ${ }^{3}$ and Fishman ${ }^{4}$ did not specify it clearly. Moreover we know of no study to determine the best time to remove the intercostal catheter. When the lung has expanded and there is no more air leak, most would clamp the catheter for 24-48 hours. If there is no re-collapse of the lung, the catheter can be taken out. If we assume that the air leak has sealed off once the lung has fully expanded, the catheter could in theory be taken out at once without complication; hospital stay can then be shortened. We therefore undertook a prospective study to assess the efficacy of suction drainage and the optimal timing of catheter removal.

\section{Methods}

Between mid-1979 and mid-1980, 53 consecutive patients with spontaneous pneumothorax treated by intercostal catheter drainage at the University Medical Unit, Queen Mary Hospital, Hong Kong

Address for reprint requests: Dr SY So, University Medical Unit, Queen Mary Hospital, Hong Kong. were entered into the study. It is the practice of the hospital to admit all symptomatic patients with spontaneous pneumothorax or those with over $20 \%$ pneumothorax into medical wards first. A 13FG disposable polyethylene catheter was introduced via a trocar through the anterior second interspace or the lateral fourth interspace. Patients were randomly allocated into one group with immediate suction drainage or another group without suction. Suction was provided by either the Gomco thoracic pump or the Puritan suction regulator. Suction pressure was initially set at $8 \mathrm{~cm} \mathrm{H} \mathrm{H}_{2} \mathrm{O}$. If it was not satisfactory after 24 hours, it was increased up to $20 \mathrm{~cm} \mathrm{H}_{2} \mathrm{O}$. Patients from each group were further allocated randomly into two subgroups. In subgroup 1 (early removal) the catheter was removed, without previous clamping, once the lung was fully expanded on daily chest radiography, and there was no evidence of air leak. In subgroup 2 (late removal) the catheter was left in situ for two days after the lung was fully expanded; when there was no more air leak it was then clamped for one day and taken out if there was no collapse of the lung after clamping of the catheter. All patients gave informed consent.

Treatment was considered to be unsuccessful if the lung did not expand fully after 10 days or it recollapsed within two days of catheter removal. All patients were followed up for at least two months to assess the recurrence rate. Statistical analysis was done using the $\chi^{2}$ test. 
Table 1 Characteristics of patients studied and nature of their pneumothoraces

\begin{tabular}{llll}
\hline Characteristic & \multicolumn{3}{l}{ Spontaneous pneumothorax } \\
\cline { 2 - 4 } & Primary & Secondary & Total \\
\hline Patient numbers & 23 & 30 & 53 \\
Sex M:F & $22: 1$ & $29: 1$ & $26: 1$ \\
Age Mean & 24 & 56 & \\
Range & $18-34$ & $40-83$ & \\
R side to L side & $1: 1$ & $1: 1$ & \\
Known previous episod: & $4(17 \%)$ & $10(33 \cdot 3 \%)$ & $14(26 \cdot 4 \%)$ \\
Extent $\geqslant 50 \%$ & $13(57 \%)$ & $11(37 \%)$ & $24(45 \cdot 3 \%)$ \\
Success & $12(52 \%)$ & $16(53 \%)$ & $28(53 \%)$ \\
\hline
\end{tabular}

\section{Results}

There were 53 spontaneous pneumothoraces in 53 patients. Twenty-three patients were classified as having primary pneumothorax when no obvious underlying lung disease was present. Thirty patients had secondary spontaneous pneumothorax when there was obvious underlying lung disease; 25 of the latter had chronic bronchitis and emphysema and five had pulmonary tuberculosis. Table 1 shows the patient characteristics and the nature of their pneumothoraces. All patients had chest pain or dyspnoea or both on admission. None had tension pneumothorax or haemothorax. There was no bilateral pneumothorax. As expected, male patients predominated, and primary spontaneous pneumothorax occurred in the younger age group. Patients with secondary pneumothorax had more known previous episodes and less extensive pneumothorax; this was because they had poor respiratory reserve and developed symptoms more readily. The overall success rate was only $53 \%$, irrespective of the nature of pneumothorax.

Table 2 shows that suction drainage had a success rate of $50 \%$ and non-suction drainage, $57 \%$. Results were similar for both primary and secondary pneumothorax. The suction group had similar extent of pneumothorax and duration of hospital stay as non-suction group. No pulmonary oedema occurred in those with suction drainage. So far no patient with suction drainage has had recurrence of pneumothorax.

Table 3 shows that there was no difference in success rate whether the catheter was removed early or late. This seemed to apply for both primary and secondary pneumothorax, although patients in the late removal group had more extensive secondary pneumothorax. However most of the failure in the early removal group was caused by re-collapse of the lung, whereas most of the failure in the late removal

Table 2 Summary of outcome from suction and non-suction drainage

\begin{tabular}{|c|c|c|c|}
\hline & Pneumothorax & No suction & Suction \\
\hline Success rate & $\begin{array}{l}\text { Primary } \\
\text { Secondary } \\
\text { Total }\end{array}$ & $\begin{array}{c}6 / 11(54 \%) \\
7 / 12(58 \%) \\
13 / 23(57 \%)\end{array}$ & $\begin{array}{c}6 / 12(50 \%) \\
9 / 18(50 \%) \\
15 / 30(50 \%)\end{array}$ \\
\hline $\begin{array}{l}\text { Extent of pneumothorax } \\
(\geqslant 50 \%)\end{array}$ & $\begin{array}{l}\text { Primary } \\
\text { Secondary } \\
\text { Total }\end{array}$ & $\begin{array}{r}6 / 11(54 \%) \\
4 / 12(33 \%) \\
10 / 23(43 \%)\end{array}$ & $\begin{array}{r}5 / 12(42 \%) \\
7 / 18(39 \%) \\
11 / 30(37 \%)\end{array}$ \\
\hline $\begin{array}{l}\text { Hospital stay } \\
\text { (days) }\end{array}$ & $\begin{array}{l}\text { Primary } \\
\text { Secondary } \\
\text { Total }\end{array}$ & $\begin{array}{l}4 \cdot 0(2-7) \dagger \\
4 \cdot 0(2-6) \\
4 \cdot 0(2-7)\end{array}$ & $\begin{array}{l}5 \cdot 0(3-7) \\
5 \cdot 0(3-10) \\
5 \cdot 0(3-10)\end{array}$ \\
\hline Recurrence & $\begin{array}{l}\text { Primary } \\
\text { Secondary }\end{array}$ & $\begin{array}{l}-(90 \text { days }) \ddagger \\
2 / 12 \text { (220 days) }\end{array}$ & $\begin{array}{l}\text { - (297 days) } \\
\text { - (213 days) }\end{array}$ \\
\hline
\end{tabular}

+ Mean duration; range in brackets

‡ Longest length of follow-up

Table 3 Success rate according to early or late removal of catheter

\begin{tabular}{|c|c|c|c|c|}
\hline & Pneumothorax & Early removal & Late removal & Statistical significances \\
\hline Success rate & $\begin{array}{l}\text { Primary } \\
\text { Secondary } \\
\text { Total }\end{array}$ & $\begin{array}{r}4 / 12(33 \%) \\
9 / 13(69 \%) \\
13 / 25(52 \%)\end{array}$ & $\begin{array}{r}8 / 11(72 \%) \\
7 / 17(41 \%) \\
15 / 28(53 \%)\end{array}$ & $\begin{array}{l}\text { NS } \\
\text { NS } \\
\text { NS }\end{array}$ \\
\hline $\begin{array}{l}\text { Extent of pneumothorax } \\
\quad(\geqslant 50 \%)\end{array}$ & $\begin{array}{l}\text { Primary } \\
\text { Secondary } \\
\text { Total }\end{array}$ & $\begin{array}{l}5 / 12(42 \%) \\
1 / 13(8 \%) \\
6 / 25(24 \%)\end{array}$ & $\begin{array}{r}6 / 11(54 \%) \\
10 / 17(59 \%) \\
16 / 28(57 \%)\end{array}$ & $\begin{array}{l}\text { NS } \\
p<0.01 \\
\text { NS }\end{array}$ \\
\hline $\begin{array}{l}\text { Hospital stay } \\
\text { (days) }\end{array}$ & $\begin{array}{l}\text { Primary } \\
\text { Secondary } \\
\text { Total }\end{array}$ & $\begin{array}{l}2.0(2-3) \dagger \\
4.0(2-6) \\
3 \cdot 5(2-6)\end{array}$ & $\begin{array}{l}5 \cdot 5(4-7) \\
6 \cdot 0(4-10) \\
6 \cdot 0(4-10)\end{array}$ & \\
\hline Recurrence & $\begin{array}{l}\text { Primary } \\
\text { Secondary }\end{array}$ & $\begin{array}{l}-(93 \text { days }) \ddagger \\
1 / 13 \text { (181 days })\end{array}$ & $\begin{array}{l}- \text { (229 days) } \\
1 / 17 \text { (262 days) }\end{array}$ & \\
\hline
\end{tabular}

+ Mean duration; range in brackets

$\ddagger$ Longest length of follow-up 
group was caused by failure of expansion, possibly related to more extensive pneumothorax. The early removal group spent an average of three and a half days in hospital; the late removal group, six days. No complication such as empyema developed for the late removal group. Both groups have had one recurrence so far.

\section{Discussion}

Since reabsorption of air from a sealed off spontaneous pneumothorax is $1.25 \%$ of the radiographic lung volume per day, ${ }^{5}$ most would use an intercostal catheter with underwater seal drainage to evacuate the air in order to save time when the pneumothorax is larger than $20 \%$ or is accompanied by dyspnoea. Theoretically suction drainage would hasten the process further. We deliberately chose suction apparatus with high flow rates rather than the conventional Roberts' pump so that a large volume of air could be removed rapidly. The suction pressure chosen was also in accordance with that recommended. ${ }^{6}$ However our result showed that lung expansion was neither better or quicker with suction drainage, although no recurrence of pneumothorax occurred. On the other hand, suction may keep air leaks or bronchopleural fistulae opened by virtue of its strong negative pressure. Furthermore too rapid evacuation of air by forced suction has been known to result in unilateral pulmonary oedema. ${ }^{7}$ Suction, therefore, offers no advantage and at times may be dangerous.

If the intercostal catheter can be removed without previous clamping once the lung had expanded and no complication followed, then time and money will be saved. Although early catheter removal achieved the same success rate as late removal, re-collapse of the lung occurred in most unsuccessful cases. Hence early removal is not desirable.

Our study had a low success rate of only $53 \%$. Others reported a yield of $70-90 \%{ }^{8}$ There are three main reasons for this. Firstly, the catheter chosen is rather small in size, so that it is easily blocked by either fluid inside or by external kinking. We chose this catheter according to Morris ${ }^{9}$ for its relative ease of insertion and painlessness compared with the Malecot catheter. Secondly, synthetic catheters do not induce irritation or adhesion so readily as do rubber drains. ${ }^{10}$ Thirdly, insertion of the catheter was done by over 10 registrars who obviously varied in their skill; $50 \%$ of the failure was the result of poorly positioned catheters.

In conclusion, we believe that for better drainage of spontaneous pneumothorax, larger sized catheters, such as $22-28 \mathrm{FG}$ ones, preferably made of rubber, should be used. If they are properly placed, suction offers no additional advantage. Once the lung has expanded and there is no more air leak, the catheter is clamped for 24 hours. If there is no recollapse of the lung, the catheter can then be taken out.

We thank the registrars for their help and Miss Susie Yim for secretarial assistance.

\section{References}

${ }^{1}$ Crofton J, Douglas A. Respiratory disease. Second edition. Oxford: Blackwell Scientific Publications, 1975

${ }^{2}$ Holman CW, Muschenheim C. Bronchopulmonary diseases and related disorders. Maryland: Harper and Row, 1972.

${ }^{3}$ Hinshaw HC, Murray JF. Diseases of the chest. Fourth edition. Philadelphia: WB Saunders, 1980.

${ }^{4}$ Fishman AP. Pulmonary diseases and disorders. New York: McGraw Hill, 1980.

${ }^{5}$ Kircher LT Jr, Swartzel RL. Spontaneous pneumothorax and it treatments. JAMA 1954;155:24-9.

- Freitag JJ, Miller LW. Manual of medical therapeutics. Twenty-third edition. Boston: Little, Brown and Company, 1980.

${ }^{7}$ Childress ME, Moy G, Martha M. Unilateral pulmonary oedema resulting from treatment of spontaneous pneumothorax. Am Rev Respir Dis 1971;104:119-21.

${ }^{8}$ Killen DA, Gobbel WG. Spontaneous pneumothorax. Boston: Little and Brown, 1968.

9 Morris MDR. Spontaneous pneumothorax. $\mathrm{Br}$ Med $J$ $1966 ; 26: 420$.

10 Nohl-Oser HC. Die Behandlung des komplizierten Spontanpneumothorax mittels axillärer Thorakotomie. Thoraxchirurgie und vasculäre chirurgie 1974;22:450. 